\title{
Interactive Session: Including Ethical Discussions in your Technical Classes
}

\section{Dr. Rebecca A Bates, Minnesota State University, Mankato}

Rebecca A. Bates received the Ph.D. degree in electrical engineering from the University of Washington in 2004. She also received the M.T.S. degree from Harvard Divinity School in 1993. She is currently Professor and Chair of the Department of Integrated Engineering program at Minnesota State University, Mankato, home of the Iron Range and Twin Cities Engineering programs. She was a 2011-12 AAAS Science \& Technology Policy Fellow at the National Science Foundation.

\section{Prof. Michael C. Loui, University of Illinois, Urbana-Champaign}

Michael C. Loui is Professor of Electrical and Computer Engineering and University Distinguished Teacher-Scholar at the University of Illinois at Urbana-Champaign. His interests include computational complexity theory, professional ethics, and engineering education research. He serves as Editor of Journal of Engineering Education and as a member of the editorial boards of College Teaching and Accountability in Research. He is a Carnegie Scholar and an IEEE Fellow. Professor Loui was Associate Dean of the Graduate College at Illinois from 1996 to 2000. He directed the theory of computing program at the National Science Foundation from 1990 to 1991. He earned the Ph.D. at M.I.T. in 1980. 


\section{Interactive Session: Including Ethical Discussions in your Technical Classes}

\section{Introduction}

The power of story, fictional or not, is that people are engaged, and case studies, built on stories, take advantage of this property. The use of case studies is a recognized and powerful method for incorporating engineering ethics into engineering classrooms. However, leading interactive discussions and supporting ethical development is often an untrained skill for engineering faculty. To support ongoing faculty development amongst ASEE conference attendees and as encouraged by the newly adopted ASEE Code of Ethics (http://www.asee.org/memberresources/resources/Code_of_Ethics.pdf), an interactive technical session provides the opportunity to have an experienced teacher of ethics in engineering contexts lead attendees through a class-length case study experience, using cases chosen to address issues broad enough to relate to multiple disciplines. The focus is on undergraduate student learning and preparation for professional activity, rather than on issues related to responsible conduct of research. Issues include conflicts of interest, acknowledging mistakes, dissent, whistleblowing, environmental and safety concerns, honesty and truthfulness, organizational communication, ownership, quality control and product liability, public service, responsibility, and gender issues. ${ }^{1}$

The session allows for a class-length experience, followed by a 30-minute period to reflect on and discuss approaches to incorporating ethics discussion in classes, methods for supporting student discussion and evaluation of the experience. During the class experience attendees interact with the sample teacher as they either hope or expect their students to participate (modeling student behavior). To prepare for this, the discussion leader encourages the attendees to observe the process while reflecting on what experiences may or may not work in their own classroom.

The goal of this paper is to provide resources and information associated with this interactive "classroom" session. Curriculum information, suggestions for pedagogy, links to online and physical resources including prepared case studies, a biography of the presenters and pointers to useful information about teaching ethics follow.

\section{Background}

There are multiple approaches to teaching ethics within engineering programs, from requiring a distinct class on ethics (frequently taught by philosophy faculty) to modules incorporated in capstone or introductory courses to discussions held in multiple classes throughout the program (ethics across the curriculum). There are benefits to including philosophy faculty in the process in any approach because of the frameworks and questioning practices they bring to the table as well as a more diverse point of view that can support student learning. There are also significant benefits to incorporating ethical discussions throughout engineering learning, in particular, the obvious signal that addressing ethical issues is valued by engineering faculty and is worthy of time that is often protected for engineering technical content alone. ${ }^{2}$ Arguably, the development of a highly capable professional engineer requires ethical growth and learning. Fortunately, this kind of thinking can be viewed similarly to design thinking. ${ }^{3}$ Integrated learning of design and 
ethical thinking along with technical content can better prepare engineers for the challenges of their careers.

Because students will enter a profession where they will need to recognize ethical dilemmas and then make decisions about personal and professional responsibility within that situation, it is valuable to use active learning approaches that let them model the process. Active learning has been shown to be valuable in many engineering contexts. ${ }^{4}$ Some possible pedagogical approaches faculty can use when working with ethical discussions are small group discussions with reporting, role playing, ${ }^{5}$ academic controversy (a form of debate where participants switch sides about $2 / 3$ through the session) ${ }^{6}$ other social instruction strategies like collaborative learning, ${ }^{7}$ and legitimization of differences. ${ }^{8}$ Taking advantage of techniques like "microinsertion," will allow for more practice addressing ethical issues for students throughout their technical courses, while maintaining time spent on technical content. ${ }^{9}$

While there are many ethics textbooks available (e.g., Fleddermann, ${ }^{10}$ Martin and Schinzinger, $2009,{ }^{11}$ Martin and Schinzinger, $2005^{12}$ ), most including cases in some form, one that is particularly useful is Harris, Pritchard and Rabins ${ }^{13}$ with cases online at http://wadsworth.com/philosophy_d/templates/student_resources/0534605796_harris/cases/Case $\underline{\text { s.htm }}$ and annotated versions of some of the cases at http://ethics.tamu.edu/NSFReport.aspx. (Others are listed below in Online Resources.) While there are many cases available, there may be personal experiences that would work well as a classroom case. The connection of personal experience can strengthen the power of the case story. Developing a case requires addressing issues of clarity (and lack of), and leaving points to be discussed. ${ }^{14}$ While there may be one right answer, that is not always the case. Allowing students to struggle with the dilemma will develop their ability to recognize issues and work through the situation without expecting to know the right answer immediately.

Ethical frameworks used for evaluating dilemmas can vary depending on values. These can be complex or straightforward. One example (see Appendix), suggests that students either address things in terms of values such as honesty, fairness, civility, respect, kindness, etc. or by applying a series of tests that give students concrete questions to examine:

Harm test: Do the benefits outweigh the harms, short term and long term?

Reversibility test: Would this choice still look good if I traded places?

Common practice test: What if everyone behaved in this way?

Legality test: Would this choice violate a law or a policy of my employer?

Colleague test: What would professional colleagues say?

Wise relative test: What would my wise old aunt or uncle do?

Mirror test: Would I feel proud of myself when I look into the mirror?

Publicity test: How would this choice look on the front page of a newspaper?

\section{Approach}

The approach used for the interactive session is one of small group discussion that allows for close discussion on topics and broader discussion after ideas are organized. Attendees will be divided into groups of four to allow for input from each participant as well as potential for diverse experiences. Names will be collected on index cards at the beginning of the exercise so 
that small group "reporters" can be called by name. Groups will be given frameworks and opportunities to discuss cases (similar to those in the Appendix). Each group will be asked to identify stakeholders, consider possible actions, evaluate consequences of actions; ensure that each group member participates. Then each group will discuss its assigned case for ten minutes, with reporting out to the larger group before moving on to another case. Key issues will be highlighted by the leader as the groups report.

\section{Online Resources}

The online resources described below are taken from Bates et al., $2012^{15}$ and include the Ethics CORE (Collaborative Online Resource Environment), the National Academy of Engineering's Online Ethics Center, the $\mathrm{E}^{3}$ project, and a list of other sites with ethics information.

The Ethics CORE (Collaborative Online Resource Environment) project is an Internet portal supporting ethics education in science, social science, engineering and math. It is being developed by National Center for Professional and Research Ethics at the University of IllinoisUrbana Champaign. The online environment consists of tools like searching, developing, and contributing resources, collaborative workspaces, discussion areas, wikis and blogs as well as essays on teaching and pedagogy, videos, online courses and links to other online resources. The portal can be found at http://nationalethicscenter.org/. For example, "The Practice of Ethics in Classroom Teaching," 16 is a video showing ways to support student learning through ethical faculty behavior. All members of the engineering education community are encouraged to participate, whether by contributing resources or feedback, by actively participating in collaborative groups, or by using resources to enhance their teaching.

The Online Ethics Center, http://onlineethics.org, is a product of the National Academy of Engineering. It includes resources for responsible research, case studies, professional codes and guidelines, annotated bibliographies and a community of practitioners. Forums allow space for site users to learn more about the resource or to discuss particular case studies. Along with working through case studies, another way to use this center is to have students examine the various codes of ethics and to look at changes over time within the profession. ${ }^{17}$

The Exploring Ethical Decision Making in Engineering ( $\left.\mathrm{E}^{3}\right)$ project is a multi-institution team exploring issues related to ethical development in engineering students. Results of their work can be used to guide institutional and teaching practice to support ethical development. More information and publications can be found at http://www.engin.umich.edu/research/e3/index.html.

Other online sources for engineering ethics education are also available, primarily in the form of case studies that can be used in classes. Some examples are:

- National Institute for Engineering Ethics, Cases from the National Society of Professional Engineers Board of Ethical Review: http://www.niee.org/cases/

- Texas A\&M Engineering Ethics: http://ethics.tamu.edu/

- The Ethics Education Library at the Center for the Study of Ethics in the Professions at IIT: http://ethics.iit.edu/eelibrary/ 
- Penn State's College of Engineering Ethics:

http://www.engr.psu.edu/ethics/casestudies.asp

- Vanderbilt's Center for Ethics:

http://www.vanderbilt.edu/CenterforEthics/cases.html\#engineering

- University of Washington Engineering Education ready-to-go Tools for Teaching: http://www.ee.washington.edu/research/dms/Tools_for_Teaching/Tools_for_Teaching/H ome.html

The National Institute for Engineering Ethics (http://www.niee.org) offers DVDs of three video cases that dramatize fictional but realistic cases: Gilbane Gold, Incident at Morales, and Henry's Daughters. Loui et al. (2003) ${ }^{18}$ demonstrates how to organize discussion of Incident at Morales with small-group collaborative learning techniques.

\section{Biographies}

Michael C. Loui is Professor of Electrical and Computer Engineering and University Distinguished Teacher-Scholar at the University of Illinois at Urbana-Champaign. His interests include computational complexity theory, professional ethics, and the scholarship of teaching and learning. He serves as Editor of Journal of Engineering Education, and as a member of the editorial boards of College Teaching and Accountability in Research. He is also a member of the Advisory Group for the Online Ethics Center at the National Academy of Engineering, and the Executive Board of the National Institute for Engineering Ethics. He is a Carnegie Scholar and an IEEE Fellow.

Rebecca Bates is serving as the discussion leader. She is a Professor of Computer Science \& Integrated Engineering at Minnesota State University, Mankato. She directs the Iron Range and Twin Cities Engineering programs, which integrate technical, design and professionalism content in an upper-division, project-based learning curriculum. She was a 2011-12 AAAS Science and Technology Policy Fellow at the Division of Engineering Education \& Centers in the National Science Foundation and received a Fulbright to Brazil in 2009-10.

\section{Summary}

It is not unusual for faculty to teach outside of their comfort zone, but this is often defined in terms of technical competencies. Teaching ethical thinking can be a challenge since the methods and "answers" often appear to be different from typical classes. The goal of this interactive session and paper is to provide experiences and resources that can support faculty members in incorporating more ethical discussions and decision making experiences in their engineering classes. Readers are encouraged to participate in the online forums described here. 


\section{References}

[1] Center for the Study of Ethics in Society. 1992. Teaching engineering ethics: a case study approach. Pritchard, M., editor. http://ethics.tamu.edu/NSFReport.aspx. Accessed January 6, 2013.

[2] Davis, M. 1999. Teaching ethics across the engineering curriculum. Presented at the OEC International Conference on Ethics in Engineering and Computer Science, March 1999. Available at http://www.onlineethics.org/Education/instructessays/curriculum.aspx. Accessed January 6, 2013.

[3] Whitbeck, C. 1995. Teaching ethics to scientists and engineers: moral agents and moral problems. Science and Engineering Ethics 1(3), pp. 299-308.

[4] Prince, M. 2004. Does active learning work? A review of the research. Journal of Engineering Education, 93 (3), 223-231.

[5] Loui, M. 1999. Role playing in an engineering ethics class. Presented at the OEC International Conference on Ethics in Engineering and Computer Science, March 1999. Available at http://www.onlineethics.org/Education/instructguides/loui2.aspx. Accessed January 6, 2013.

[6] Johnson, D., Johnson, R., and Smith, K. 1997. Academic Controversy. Enriching College Instruction through Intellectual Conflict. ASHE-ERIC Higher Education Report Volume 25, No. 3. Washington, DC: The George Washington University, Graduate School of Education and Human Development. Available at http://www.eric.ed.gov/PDFS/ED409829.pdf. Accessed January 6, 2013.

[7] Barkley, E., Cross, K.P. and Major, C. H. 2005. Collaborative Learning Techniques: A Handbook for College Faculty. San Francisco: Jossey-Bass.

[8] Wilson, D., et al., "Engineering Education Technique" Accessed: Sunday, January 6, 2013 http://www.ee.washington.edu/research/dms/Tools_for_Teaching/Tools_for_Teaching/Technique.html.

[9] Davis, M. 2006. Integrating ethics into technical courses: micro-insertion. Science and Engineering Ethics 12(4), pp. 717-730.

[10] Fleddermann, C. B. 2007. Engineering Ethics. 3rd ed. Prentice Hall.

[11] Martin, M. W., and Schinzinger, R. 2009. Introduction to Engineering Ethics. 2nd ed. New York: McGrawHill.

[12] Martin, M. W., and Schinzinger, R. 2005. Ethics in Engineering. 4th ed. New York: McGraw-Hill.

[13] Harris, C. E., Jr., Pritchard, M. S. and Rabins, M. J. 2008. Engineering Ethics: Concepts and Cases. 4th ed. Belmont, Calif.: Wadsworth.

[14] Michael Davis, 1997. Developing and using cases to teach practical ethics. Teaching Philosophy, vol. 20, no. 4, pp. 353-385.

[15] Bates, R., Broome, Jr., T., Burge, Jr., L., Hollander, R., Loui, M. 2012. Ethics education \& resources: a summary of issues facing the field and resources to address them. Proc. 2012 American Society for Engineering Education Annual Conference \& Exposition, June 2012.

[16] "The Practice of Ethics in Classroom Teaching" Ethics CORE Resources. Accessed: Sunday, January 6, 2013 http://nationalethicscenter.org/resources/807.

[17] "Ethics Codes and Guidelines" Online Ethics Center for Engineering 7/27/2009 National Academy of Engineering Accessed: Sunday, January 06, 2013 http://www.onlineethics.org/Resources/ethcodes.aspx.

[18] Loui, M.C., LeFevre, E.W., Nichols, S.P., Skooglund, C.M., Smith, J.H., Suppe, F., Ullmer, P.E. andWeil, V. 2003. Incident at Morales: an engineering ethics video, Proc. of the Thirty-Third ASEE/IEEE Frontiers in Education Conference, Westminstoer, CO, November 5-8, 2003, pp. S1H-1 to S1H-2. DOI: 10.1109/FIE.2003.12565931. 


\section{Appendix: Classroom Materials}

ME 390

Scenarios in Engineering Ethics

Spring 2010

\section{A General Approach to Ethical Problems}

1. Identify the affected parties, their interests (rights, expectations, desires), and their responsibilities. Determine what additional information is needed.

2. Consider alternative actions by the main actors, and their possible consequences.

3. Evaluate those actions and consequences according to basic ethical values-honesty, fairness, civility, respect, kindness, etc.—or the following tests:

Harm test: Do the benefits outweigh the harms, short term and long term?

Reversibility test: Would this choice still look good if I traded places?

Common practice test: What if everyone behaved in this way?

Legality test: Would this choice violate a law or a policy of my employer?

Colleague test: What would professional colleagues say?

Wise relative test: What would my wise old aunt or uncle do?

Mirror test: Would I feel proud of myself when I look into the mirror?

Publicity test: How would this choice look on the front page of a newspaper?

\section{Scenario \#1: Responsibility}

Engineering student Bryan Springer has a high-paying summer job as a forklift operator, which enables him to attend college without having to take out any student loans. He is now staring at a 50-gallon drum filled with used machine coolant, wondering what he should do.

Just moments ago, Bryan's supervisor, Max Morrison, told him to dump half of the used coolant down the drain. Bryan knew the coolant was toxic, and he mentioned this to Max. But Max was not swayed.

Max: The toxins settle at the bottom of the drum. If you pour out half and dilute it with tap water while you're pouring it, there's no problem.

Bryan: I don't think that's going to work. Besides, isn't it against the law?

Max: Look, kid, I don't have time for chit-chat about a bunch of silly laws. If I spent my time worrying about every little regulation that comes along, I'd never get anything done-and neither will you. Common sense is my rule. I just told you - toxins settle at the bottom, and most of them will stay there. We've been doing this for years, and nothing's happened.

Bryan: You mean no one's said anything about it? That doesn't mean the environment isn't being harmed.

Max: You aren't one of those "environmentalists," are you? You college guys spend too much of your time in the ivory tower. It's time to get real - and get on with the job. You know, you're very lucky to have a good-paying job like this, kid. In three months you'll be back in your cozy college. Meanwhile, how many other college kids do you think there are out there wondering if they'll be able to afford to go back-kids who'd give their eye teeth to be where you are right now?

Max then left, fully expecting Bryan to dump the used coolant. As Bryan stares at the drum, he ponders his options. What options do you think he has? What do you think he should 
do? First identify the responsibilities of Bryan, Max, and Bryan's employer. (Scenario by Michael Pritchard)

\section{Scenario \#2: Conflict of Interest}

Beth I. Beam is a civil engineer at the federal General Services Administration (GSA). In the next month, GSA plans to let an engineering design contract for a new federal building to one of three firms, whichever appears to be most capable of performing the work. At a social gathering one night, Beth is approached by Sam Steel, a manager at one of the firms, Colossus Construction Consultants. Sam suggests that if Colossus receives the contract, then Beth could come to work for Colossus at a considerable increase in salary. Beth has been thinking of leaving GSA because the office location is a long commuting distance from home. She could leave, withdraw her retirement pay, and purchase a small orchard that she has been looking at for several months. The orchard is only a short distance from the offices of Colossus, located in a suburban area.

Beth makes no commitment to Sam, but keeps thinking about the advantages of the change in employment. Two weeks later, she is in a meeting with other government engineers responsible for the decision on which firm to select for the design work. The choice is narrowed to two firms, including Colossus. No decision is reached that day. They are all told to study the two proposals and then reach a decision within three days. Although Beth is not a voting member of the selection committee, she plans to try to swing the decision to Colossus by mild persuasion on one or two members of the committee. She feels that both firms are capable of designing the new building; in fact, Colossus might be in a slightly superior position.

What should Beth do? Why? (Adapted from a scenario by D. Allan Firmage)

\section{Scenario \#3: Confidentiality}

Philip Cortez reread the engineering director's memo with considerable anxiety. It read: "Call me at your earliest convenience about design specs for new radial."

"New radial" - that could mean only one thing: that his employer, National Rubber and Tire, wanted to beat its biggest competitor, Lifeworth, in getting an 80,000-mile, puncture-proof tire on the market.

Ordinarily such a memo would signal a challenge for an employee as conscientious and industrious as Phil Cortez. But until six months ago Cortez had been employed by Lifeworth. While there, he had been instrumental in drawing up designs for a similar tire that Lifeworth was not only interested in producing, but was also counting on to revitalize its sagging profits. When Cortez announced his departure, Lifeworth's president reminded Cortez that the design concepts for the new radial were classified, even though they were small, unpatentable refinements of well known manufacturing techniques for tires. Cortez assured the president that he anticipated no difficulties, since he believed that National wanted him primarily in a managerial capacity.

And now the memo was staring him in the face. Cortez responded to it that very afternoon and had his worst fears realized. As he'd suspected, the engineering director solicited Cortez's input on the matter of a new radial.

Cortez explained that he would rather not work on the new radial, to avoid divulging Lifeworth's trade secrets. While sympathetic to Cortez's predicament, the director broadly hinted that refusal to provide constructive input would result in a substantial disservice to National and was bound to affect Cortez's standing with the firm. "After all," the director said, "it's very difficult to justify paying your salary when your allegiances seem to lie elsewhere." 
What should Phil do? Why? (Adapted from a scenario by Vincent Barry)

\section{Resources}

C. E. Harris, M. S. Pritchard, and M. J. Rabins, Engineering Ethics: Concepts and Cases, $4^{\text {th }}$ ed., Wadsworth/Thompson Learning, Belmont, Calif., 2009.

M. W. Martin and R. Schinzinger, Ethics in Engineering, $4^{\text {th }}$ ed., McGraw-Hill, 2005. ECE/Philosophy 316, Engineering Ethics: < http://courses.engr.illinois.edu/ece316/> Online Ethics Center at the National Academy of Engineering: <http://onlineethics.org> 